\title{
On Mesostrobus, a New Genus of Lycopodiaceous Cones from the Lower Coal Measures, with a Note on the Systematic Position of Spencerites.
}

\author{
BY
}

D. M. S. WATSON, B.Sc.,

Beyer Fellow of the Geological Department of the Victoria University of Manchester.

\section{With Plate XXVII, and six Figures in the Text.}

I N I907 the Manchester Museum received from Mr. Lomax, of Bolton, a series of four transverse sections of a cone from the Mountain $4 \mathrm{ft}$. Mine of Cloughfoot, Dulesgate. Mr. Lomax had recognized the specific distinction of the cone from all yet described, and has published a photograph of a section in a work on Coal, by Mr. J. Tonge. Prof. Weiss very kindly handed the sections over to me, and I now wish to offer some description of them.

Of the four sections, the uppermost only shows the sterile portion at the top of the cone, and the lowest is through a part of the cone that had been badly damaged before fossilization; only the middle two are therefore of much use in gaining an idea of the arrangement of the parts of the cone, and one of these two has somewhat broken up during the process of grinding the section. The sections are, however, enough to enable one to give a fairly complete account of the whole structure of the cone. The axis of the cone is $2.6 \mathrm{~mm}$. in diameter (Pl. XXVII, Phot. I).

The wood is small, only $0.34 \mathrm{~mm}$. in diameter, and is solid, there being no pith (Phot. 3 and $4 x y$ ). The protoxylems apparently do not project much, and are not very well preserved. The main mass of the wood is composed of tracheids of nearly equal lumen, which do not seem to pass by any easy transition to the smaller tracheids of the protoxylem, which appear to form small groups on the outside edge of the wood. The wood is succeeded by an ill-preserved belt of tissue which includes, no doubt, the phloem and (?) pericycle (Phot. 4). This layer shows that the phloem was broken up by patches of parenchyma on the inside of the leaf traces in the way common in the Lepidodendra.

[Annals of Botany, Vol. XXIII. No. XCI. July, I9og. 
It is succeeded by a zone of parenchyma, seven or eight cells wide, which is composed of isodiametric cells about $0.015 \mathrm{~mm}$. in diameter; this belt is the zone, called by Bower, Weiss, and myself the inner cortex; it has a definite termination outwardly, and is succeeded by the middle cortex. This forms a zone about $0.16 \mathrm{~mm}$. in breadth (Phot. 3 and 4 ). It is composed of isodiametric cells about $0.05 \mathrm{~mm}$. in diameter, which have large air spaces between them. It is not very well preserved, but this is, I believe, the first Lepidodendroid cone, except Lepidostrobus Brownii, in which it has been at all fit for description. It resembles exactly the middle cortex of any small Lepidodendroid twig, and bears a particularly close resemblance to that of an undescribed Lepidostrobus, of which I possess sections.

The middle cortex changes suddenly into the outer cortex (Phot. 3). This latter consists of a parenchymatous tissue which is strengthened by a sclerized ${ }^{1}$ skeleton. The parenchymatous foundation is composed of cells which are isodiametric in transverse section, and about $0.04 \mathrm{~mm}$. in diameter; so far as can be seen from transverse sections, the sclerized portions are composed of cells of exactly similar size and shape.

The sclerized skeleton is associated with the insertion of the sporophylls, and is arranged roughly as follows (Phot. I) :-

At the lowest point, where the sporophyll-trace is just emerging from the inner cortex, it forms, as seen in transverse section, a small patch on the inner side of the outer cortex. Followed upwards this patch enlarges radially until, where the leaf-trace begins to turn out from the middle cortex to the outer cortex, it forms a somewhat narrow plate extending radially across the entire outer cortex. This gradually broadens tangentially until it is the entire width of the base of the sporophyll. In this region the trace passes out through a non-sclerized passage in the sclerized tissue. Above the insertion of the sporophyll the sclerized patch gradually contracts, appearing last at the outer edge of the cortex. It is very hard to be sure of the exact details of the arrangement of this skeleton owing to lack of sufficient sections, and to the fact that it is probably liable to considerable individual variation in detail. The foregoing account is, I believe, in the main correct. These patches obviously serve to afford a firm attachment for the sporophyll.

The sporophylls are probably inserted on the stem in a series of spirals, they are at any rate not in whorls.

They are composed of a more or less horizontal portion, and a vertical lamina on the surface of the cone. The horizontal portion is triangular in tangential section (Phot. 5), the upper surface being flat and the under side provided with a fairly sharp keel. The upper portion is of considerable breadth, measuring at its attachment to the axis as much as $\mathrm{I} \cdot 2 \mathrm{~mm}$. across,

1 This word is used throughout in a purely descriptive sense. 
it retains this width until it expands into the base of the lamina (Phot. I and 4).

The horizontal portion is composed of somewhat thick-walled cells which are slightly elongated radially. It is traversed throughout its entire length by the vascular bundle, which passes straight through it. The wood of this bundle arises from the wood of the main axis and ascends steeply through the phloem and inner cortex, as is shown by the number of traces met with in this region in transverse section. It passes quickly through the

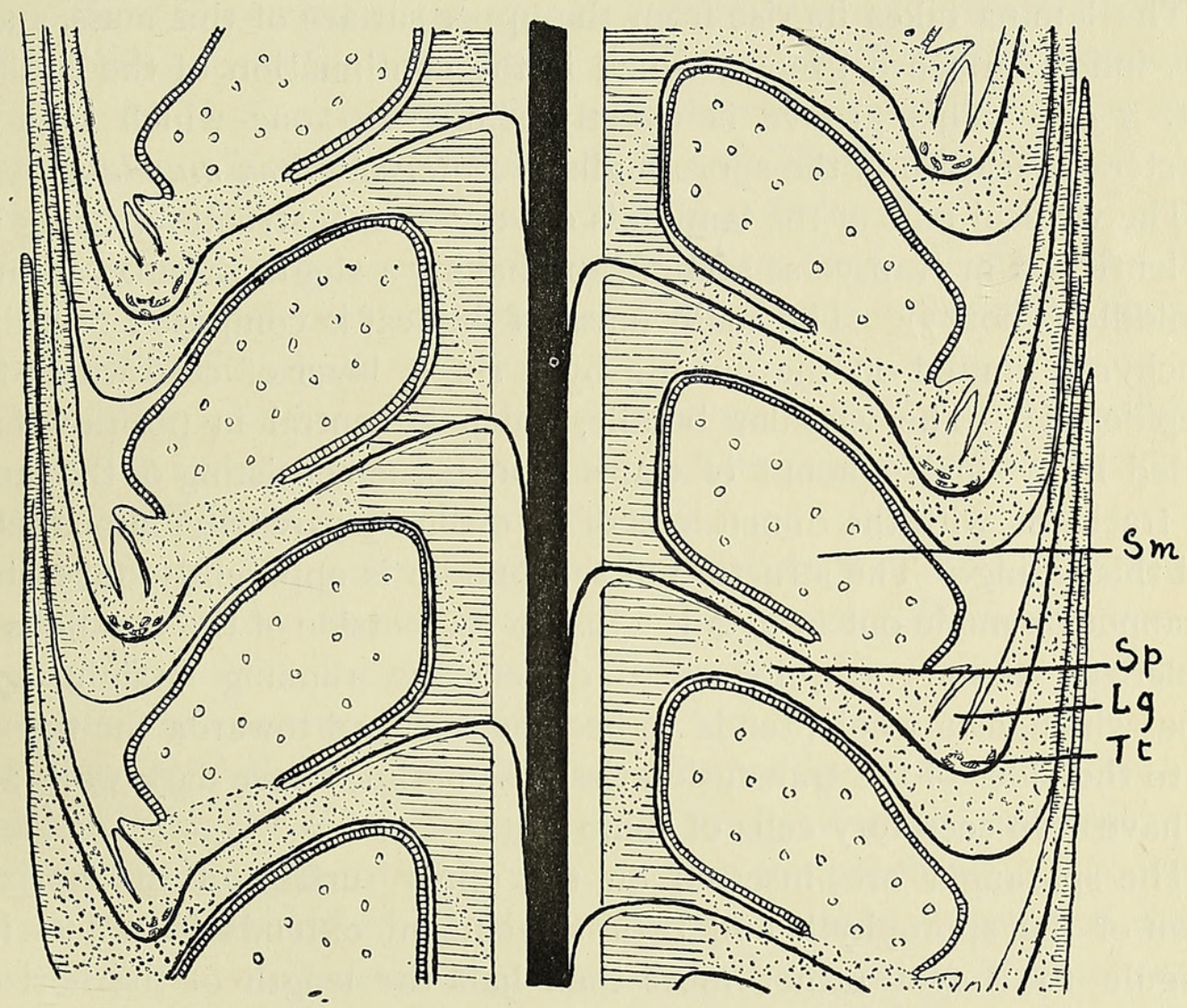

TEXT-FIG. I. Diagrammatic median longitudinal section of a cone of Mesostrobus Scottii. XI 2 approx. The sporophylls should not be superposed, but there is evidence for all other characters shown. Black $=$ vascular tissue $;$ White $=$ middle cortex and parichnos; Horizontal lines $=$ sclerized areas; Dotting $=$ parenchyma. $L g=$ Ligule ; $T t=$ Transfusion tracheids at its base $; S m=$ Sporangium ; $S p=$ Sporophyll.

middle cortex and into the outer cortex, into which it is accompanied by only a very small strand of middle cortex as a parichnos. In its course through the outer cortex it is surrounded by a sheath of parenchyma which fills up the hole in the plate of sclerized tissue which supports the sporophyll. In the mid-region of the horizontal portion I have not been able to see any definite parichnos, but I believe it occurs further out, as will be shown later.

The horizontal portion of the sporophyll at about 3 or $4 \mathrm{~mm}$. from the axis broadens out tangentially and vertically to form a solid mass, which is the base of the lamina (Phot. 6 and 7); in this region the bundle takes 
a curve downwards, forming a sort of pocket, the upper surface of which is richly lined with transfusion tracheids. This pocket surrounds the base of the ligule, which is set in a deep pit, over the edge of which its tip probably did not rise.

I believe that in this region the parichnos bifurcates, at any rate there are two patches of tissue, one on each side of the vascular bundle, which are often defective, and when present resemble in appearance some examples of the parichnos of Lepidodendron leaf-bases; these areas are, however, less well defined than the parichnos of ordinary leaf-bases.

The lamina takes its rise from the upper surface of this mass, and has on its inner surface a groove, which is the continuation of the ligular pit (Phot. $7 g r$ ). This groove is exactly similar to one which is a very characteristic feature in the sporophylls of Bothrodendron mundum.

The vertical part of the lamina is of very simple structure, being regularly lenticular in transverse section, and having a single vascular strand up the middle (Phot. 7). The main mass of the leaf is composed of ordinary parenchyma limited on the outside by a single layer of cells which forms the epidermis. The vascular bundle, which is central in position, is surrounded by a small amount of transfusion tissue consisting of the familiar short tracheids, with the dimensions of an ordinary parenchymatous cell and spiral thickening. The structure of the bundle is apparently quite simple, but cannot be made out in detail. Just to the outside of the bundle is a rib of sclerized tissue of quite small dimensions, running straight up the lamina, which, as a whole, tends to become sclerized towards the tip. The cells to the sides of the transfusion tissue sometimes have dark walls; they may have been secretory cells of some sort.

The sporangia are inserted on the upper surface of the horizontal portion of the sporophyll, and their attachment extends from just inside the ligule to a spot rather more than half the length of the horizontal portion from the axis (Phot. I, 4, and 5). They are thus only attached to the distal half of the sporophyll. Their attachment is narrow tangentially, exactly resembling in this respect that of Lepidostrobus (Phot. 5). Diagram I will convey a much clearer idea of this arrangement than any amount of description.

In the actual cone under consideration the sporophylls incline downwards, and I think that this character is normal, and not the result of postmortem crushing; at any rate this inclination enables one to settle the question of the length of the attachment of the sporangium quite definitely, for it gives a series of sections across the upper surface of the sporophyll at measurable distances from the axis.

The sporangia are not well preserved, but their wall appears to be only one cell thick, and of the normal Lepidostrobus type. In section parallel to the surface, however, the cells (although isodiametric) are seen to be 
arranged in rows, somewhat recalling the arrangement of the cells of the prosenchymatous sporangial wall of Spencerites.

The spores themselves are not definitely preserved in any sporangium but two brown masses of ill-preserved material in the lowest section of the series may represent decayed masses of microspores.

The cone which has been described above differs from all other described Lycopodiaceous cones in the manner of attachment of the sporangia. In its general characters it much resembles Lepidostrobus, and I think is undoubtedly a member of the Lepidodendraceae ; at the same time the distinctly different insertion of the sporangium entitles it to generic distinction, and I beg to propose for it the name of Mesostrobus Scottii, in commemoration of Dr. D. H. Scott's connexion with the three most interesting known Lycopod cones, Spencerites, Lepidocarpon, and Miadesmia.

The genus Mesostrobus may be defined as follows :-

Lycopodiaceous cones resembling Lepidostrobus in all characters except in having the sporangium only attached to the distal portion of the horizontal portion of the sporophyll.

This diagnosis is to be regarded as provisional; it is possible, for example, that the insertion of the ligule in a deep pit may turn out to be of generic value if further species are found.

Any general discussion of the inter-relationships of the Lycopodiaceous cones has to consider especially the following types:-Bothrodendron mundum, Lepidostrobus, Lepidocarpon, Miadesmia, Lycopodium, Selaginella, Spencerites, and the cone just described.

I propose to discuss primarily the relationships of Lepidostrobus. This shows itself a highly specialized genus in the great radial extension of the sporophylls. It appears highly unlikely that the primitive Lepidodendroid had this character, and I believe its cone to be nearly represented morphologically by that of Bothrodendron mundum and the male Miadesmia.

Two cones have now been attributed to Bothrodendron; the small cone of B. mundum =(?)B. punctatum, and Bothrostrobus Olryi, Zeiller, which was found by Mr. Kidston, attached to a twig of Bothrodendron minutifolium, Boulay. This latter cone is exactly like Lepidostrobus, except that its sporophylls are in verticils, and are relatively short.

Bothrodendron is one of the most ancient genera of the Lycopodiales. In the upper Old Red Sandstone of Kiltorkan two species occur. Bothrodendron kiltorkense and the plant described as Knorria or Sagenaria Bailyana; this last plant, as I have determined from the examination of a specimen in the Manchester Museum, is undoubtedly a Bothrodendron, although of a rather curious type.

The same plants occur in the Ursa flora of Bear Island, with B. Wilkianum in addition.

The only Lycopodiaceous fructification known from Kiltorkan is 
Lepidostrobus Bailyamus Sch., which is of the ordinary Lepidostroboid type, and is heterosporous, but appears to be verticillate.

The very close general resemblance between the sporophylls of Bothrodendron mundum, Miadesmia, and Selaginella is an interesting feature. It is fairly certain that Selaginella and Bothrodendron are not very closely related, and I do not think that there is much more connexion between Miadesmia and Selaginella.

The evidence connecting Miadesmia and Selaginella is only that they are both herbaceous forms of ligulate Lycopods, with heterosporous cones and short sporophylls. Miss Benson ('08) in addition points out that the Miadesmia stem resembles that of some Selaginellae in its wood, and in the presence of trabeculae, probably representing the endodermis.

The wood certainly resembles fairly closely that of some vertical Selaginellas, but it resembles equally closely that of many small Lepidodendroid twigs.

The layer of trabeculae does not show up very well in any of the fairly numerous sections of Miadesmia stems that I have now examined, and it might apparently represent the middle cortex of the Lepidodendraceae, some types of which it considerably resembles. Heterospory combined with a ligule and a short sporophyll is met with in Bothrodendron mundum in a form which greatly resembles that of Miadesmia.

There is, I think, no doubt that the Lepidodendraceae were a dominant group in the Carboniferous period, the very great specialization reached by Lepidocarpon, and shown generally by the Halonial branches and Ulodendroid scars is, I think, proof of this.

It is a general rule that a dominant group contains members of all sizes and fitted for many different conditions, for example, the Deinosaurs, the dominant group of land animals during the mesozoic, are represented equally by the giant Sauropods, Diplodocus and Atlantosaurus, 80-100 ft. long, and by the little Compsognathus about as big as a rook and quite as lightly built.

In just the same manner one would, a priori, expect the Lepidodendraceae to be represented by herbaceous forms as well as by forest trees, and it is possible that in Miadesmia we have one of the herbaceous forms we should thus theoretically expect. So far as I know there is no evidence to prohibit this view, although there is little in its favour; at any rate the evidence is as strong as for its relationship to Selaginella.

If these three forms are not closely allied then the striking resemblances between their cones must be due to one of three causes :-

I. That their distant common ancestor had a cone of this type, and they have descended from it without modification.

2. Heterogenetic homoeomorphy, i. e. that their cones were once distinct, and have reached their present resemblances by convergence during their evolution. 


\section{Lycopodiaceous Cones from the Lower Coal Measures. 385}

3. That their cones were originally similar and have reached their present state after passing through similar series of stages; this is, I believe, expressed by Osborn's term Rectigradation.

The fact that the cones of Lycopodium and Phylloglossum agree very closely with this type, except in the absence of the ligule, I think lessens very greatly the probability of the second explanation being correct. The assumption here is that, as the ligule is an obviously important organ in the heterosporous Lycopods, it is rather unlikely that the homosporous forms should have reached the same result in its absence, starting from different material.

We are, therefore, left with two theories (the first and third above) to account for the resemblances between these cones; these theories do not differ very much, and I propose to take the first as a working hypothesis and discuss the third later.

It seems pretty safe to say that Lycopodium, Selaginella, Miadesmia, and Bothrodendron parted company a considerable time ago, and hence, assuming the first theory to be true, we may suppose that the cone of Bothrodendron mundum affords a pretty accurate representation, morphologically, of the primitive Lycopod cone, which would of course be homosporous.

Assuming this, let us investigate what would be the effect of the development of an arboreal habit by the Lepidodendraceae.

There is no doubt that it would lead to an increase in the number of spores required. This increase might be supplied in two ways.

I. By increasing the number of sporophylls, either by increasing the number of cones or adding to their length.

2. By increasing the size of the sporangium.

Increase in the number of component parts is a very clumsy method of achieving the desired result, for a cone with small sporangia has a much smaller ratio of sporogenous to sterile tissue than has a cone with larger sporangia; compare, for example, Bothrodendron mundum with Lepidostrobus.

Similar considerations show that the most efficient method of adding to the volume of a sporangium is by increasing its radial extension, for a greater height would not only increase the length of axis per sporophyll, but also the size of the lamina required for adequate protection of the spores.

Hence, simple geometrical considerations show that it is likely that the adoption of an arboreal habit would lead to a radial extension of the sporangium, assuming that such habit necessitated increased spore production.

If we suppose the stalk of the Bothrodendron mundum sporophyll to be elongated, we get an arrangement by which the radial extension of the sporangium is increased.

If we imagine this to have taken place, we are left with an arrangement recalling that of Spencerites. 
This arrangement has certain obvious disadvantages :-

I. The attachment-area of the sporangium is so limited that provision of sufficient food material to the developing spores would be a difficulty.

2. It is weak mechanically.

Both these disadvantages will be removed if we increase sufficiently the attachment area of the sporangium. This increase can only be made by extending the attachment of the sporangium down the horizontal portion of the sporophyll towards the axis.

In this way we reach a condition which is preserved for us in Mesostrobus; here we have considerable radial extension of the sporophyll combined with attachment of the sporangium to it only along its distal half. It is noteworthy that the Mesostrobus sporophyll strongly recalls that of Bothrodendron mundum.

Further continuance of this process leads directly to the ordinary Lepidostrobus (cp. Text-fig. 2).

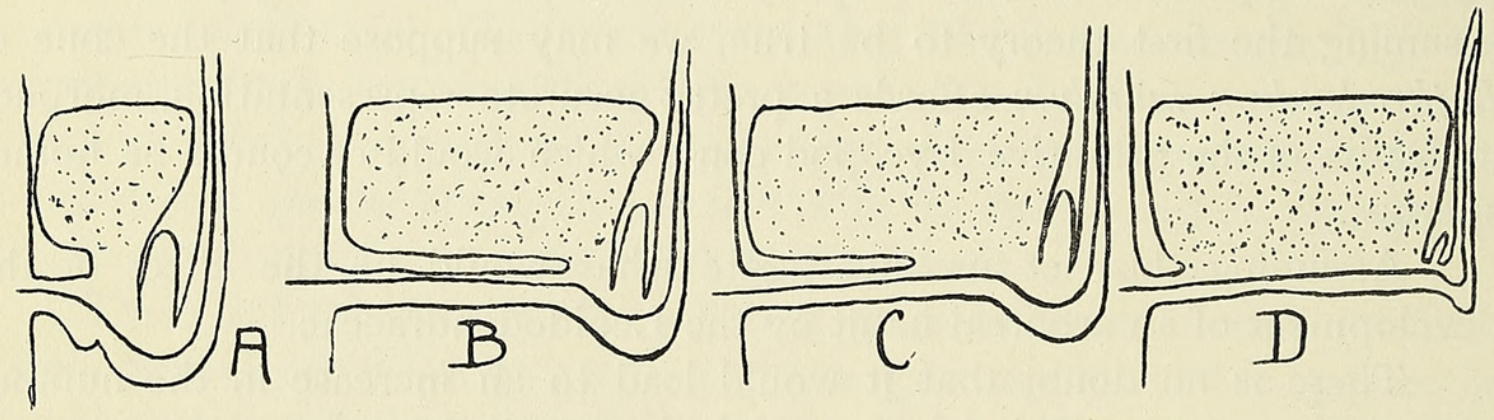

Text-Fig. 2. The rise of the Lepidostrobus condition. $A=$ Bothrodendron mundum; $B=$ Hypothetical ancestry corresponding to Spencerites; $C=$ Mesostrobus $; D=$ Lepidostrobus.

Spencerites does not appear to me at all the sort of thing one would expect, if it were a cone retaining very archaic features.

Certain specimens, at any rate, have their sporophylls arranged very regularly in alternating verticils (cp. Text-fig. 3). Now the vast majority of Lycopods have not a trace of verticillate arrangement, and where such an arrangement does occur it is usually in the case of a cone.

In a cone it is easily seen that a verticillate arrangement with alternating verticils is that which will secure adequate protection for the sporangia with the least possible area of lamina.

The importance of this saving is well illustrated by the fact that in the cone Calamostachys Binneyana, whilst the sporangiophores are superposed, the bracts are in alternating verticils; the whole leading to a very curious arrangement of leaf-traces, which is not yet understood.

A far more striking case, however, is that of Sphenophyllum Dawsoni, where, although the facts are not absolutely conclusive, it seems that the bracts alternate, although such an arrangement is hard to correlate with the vertical course of the protoxylems, and with the fact that the superposition 
of appendages is one of the most characteristic of the vegetative characters of the group.

There is hence a considerable probability that the acquirement of an alternating verticillate arrangement of appendages in the cones of a Lycopod is a specialization.

The modern stock description of Spencerites as having the sporangium attached distally to a 'ventral hump' on the sporophyll, gives only a very misleading idea of the real arrangement of the cone, which was so accurately described by Dr. Scott.

The 'ventral hump' when cut tangentially is seen to be a rhomboidal peltate head which fits very tightly on to its neighbours, forming a magnificent protection to the sporangia, compared to which that given by the weak and obviously easily damaged lamina described by Miss Berridge is negligible (cp. Text-fig. 3). It is to be noticed that the arrangement of the sporophylls in alternating verticils makes this much neater that it otherwise would be. There is thus an obvious utilitarian purpose in the 'ventral hump'.

The fact which probably impresses most strongly the student of palaeozoology is that two branches of a race which separate at an early period often pursuesimilar courses and add similar organs, as though there was some tendency in

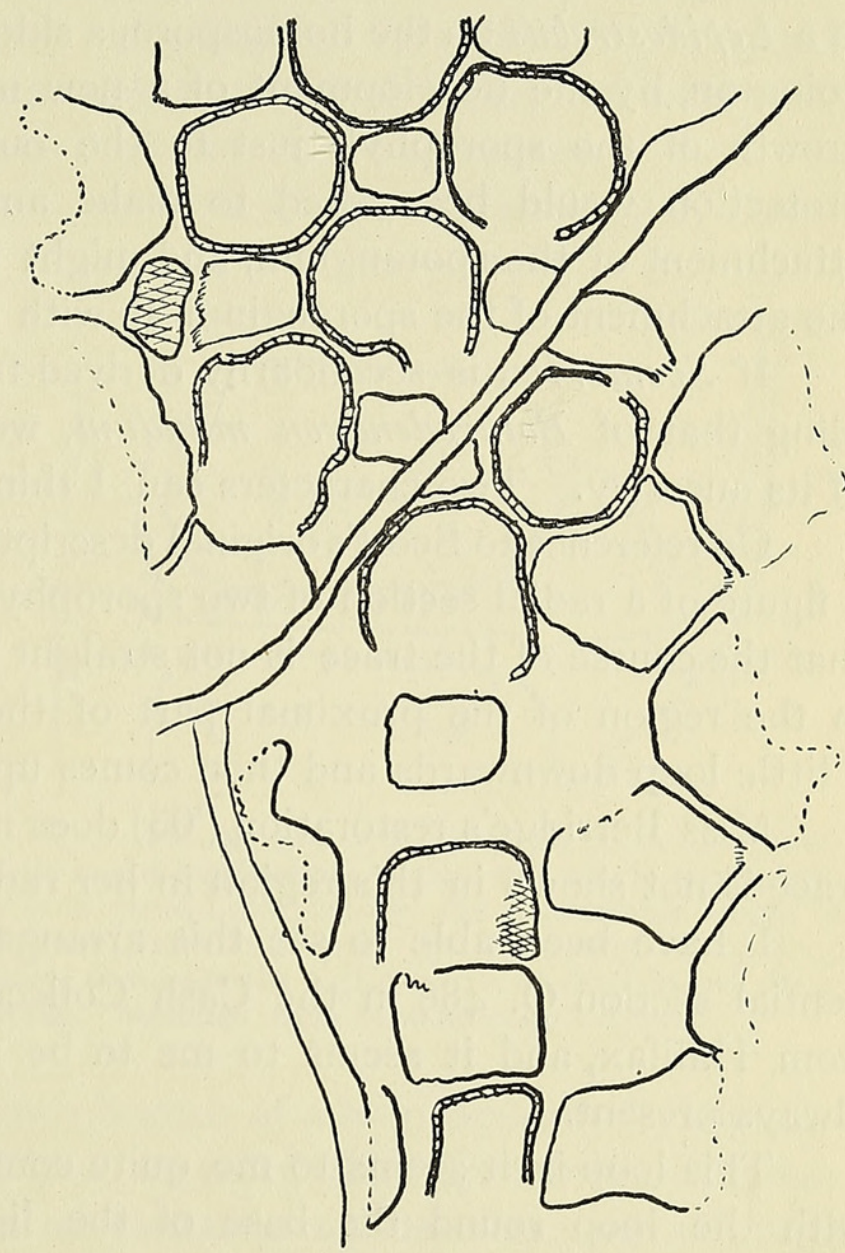

TEX'T-FIG. 3. Tangential section of a cone of Spencerites insignis (Q. 489). $\times$ I 4. Dotted lines indicate that the present edge of an organ is manifestly incomplete. The sporophylls are unshaded. The figure serves to show the way in which the sporangia fill up the entire space between the pedicels of the sporophylls, and the mechanical protection afforded to the sporangia by the peltate expansions, which are suitably cut on the right hand side in the lower part of the figure.

their original stock to produce these particular characters : this is, I believe, Osborn's 'Doctrine of Rectigradations'.

I have shown that it is possible to provide a plausible explanation of the rise of a radially elongated sporophyll in the heterosporous arboreal Lycopods, and that this sporophyll probably passed through a condition reminding one of Spencerites. 
It is quite safe to assume that the early homosporous cone did not differ much from the heterosporous cone which had just branched off from it. The causes which led to the production of Lepidostrobus, on the increase in size of the heterosporous Lycopods, would in a precisely similar manner tend to produce a similar effect on the cones of any homosporous Lycopod which similarly increased in size.

The whole would be an illustration of the Doctrine of Rectigradation. Hence, it seems possible to explain Spencerites as a stage in the production of a Lepidostrobus on the homosporous side, which has been prevented from going on, by the development of a new method of protection, by an outgrowth of the sporophyll just to the outside of the sporangium. This protection would be needed to make amends for the weak mechanical attachment of the sporangium, and might begin as a small lump and carry the attachment of the sporangium up with it.

If Spencerites is secondarily derived from a homosporous cone resembling that of Bothrodendron mundum, we should expect to see vestiges of its ancestry. Two characters can, I think, be interpreted as such.

On reference to Scott's original description (Scott, '97), Pl. XIV, Fig. I I, a figure of a radial section of two sporophylls of Spencerites insignis shows that the course of the trace is not straight through the sporophyll, but that in the region of the proximal part of the peltate head, the trace takes a little loop downwards and then comes up again.

Miss Berridge's restoration ('05) does not show this, but apparently the trace is not shown in this region in her radial section.

I have been able to see this arrangement (only very badly) in tangential section Q. 489 in the Cash Collection of the Manchester Museum, from Halifax, and it seems to me to be natural, although it may not be always present.

This loop is, it seems to me, quite comparable, and in fact homologous with the loop round the base of the ligule in Bothrodendron mundum and Mesostrobus. It may be objected that the loop is rather nearer the axis than would be expected on this view; in answer to this I would point out that in Lepidostrobus it is further out, and no longer embraces the base of the ligule.

This loop suggests that the ligule is possibly included in the 'ventral hump', a suggestion which has, I believe, been already made by Miss Berridge. In the Lycopods generally, the ligule is a very definite organ well marked off from its base, so that not very much weight should be laid on this suggestion.

Miss Berridge in her paper on Spencerites shows that the trace in passing from the outer cortex to the sporophyll rises slightly above the base and then comes down to enter it. This arrangement is exactly similar to that which occurs in Mesostrobus and probably in Bothrodendron mundum. 
That it is unlikely that Spencerites is at all a primitive cone is also shown by the fact that a prosenchymatous sporangial wall is known in no other strobiloid Pteridophyte. If it were a primitive condition we should expect to see at least traces in other Lycopods; such traces we do not find.

The fact that both species of Spencerites have elaborated spores is also against their primitive nature.

It may be objected that the sporophylls of Spencerites are really quite short. This is certainly true, but reference to Miss Berridge's paper (or Text-fig. 4) will show that if measured to the lamina they are long compared with such sporophylls as those of Bothrodendron mundum.

It is unfortunate that we know so little of the morphology of Spencerites majusculus; the analogy of Spencerites insignis should teach caution in drawing arguments from the other and rarer species.

It is at any rate interesting that Spencerites is the only homosporous Lycopod which is known to have attained to even moderate dimensions. I possess a section of a branch of Spencerites (A. 3I), duplicates of which are in the Manchester Museum Collection, over $30 \mathrm{~mm}$. in diameter. This

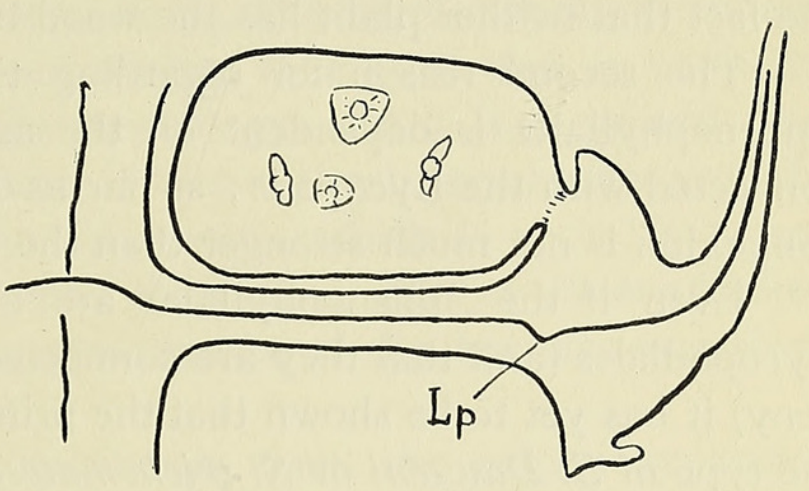

TeXT-FIG. 4. Spencerites insignis, Scott. Diagrammatic radial longitudinal section of a single sporophyll, to show general morphology, the considerable length of the limb, and the loop at $L p$ reminiscent of the loop which surrounds the ligule in Bothrodendron and Mesostrobus. Modified from Miss Berridge's figure. is, I believe, by far the largest known branch of a homosporous Lycopod.

Throughout this discussion I have assumed that Spencerites is homosporous; there is so far as I know no evidence against this, and although it is of course impossible to prove that it did not have microspores, the evidence in favour of its being homosporous seems to be considerable.

The theory that Spencerites is a cone retaining primitive characters really rests entirely on the assumption that the Lycopod cones are derived from a condition resembling that of Sphenophyllum Daresoni, and that the peculiar features of the Spencerites cone can be made to square with such ancestry.

The evidence for any connexion between the Sphenophyllales and the Lycopodiales does not seem to be of very great weight. It is entirely comprised under two heads :-

I. The general resemblance between the wood of Cheirostrohus and that of some of the Lepidodendraceae.

2. The resemblance between the pair of sporangia and the organ 
which bears them in Tmesipteris, and the sporophyll of the Sphenophyllales, particularly S. majus. This involves the assumption that Tmesipteris is related to the Lycopodiales.

The resemblance between the wood of Cheirostrobus and that of Lepidodendron is real, but does not extend to details. It seems to me that these resemblances are just what one would expect.

The resemblance really depends on the fact that exarch protoxylem is primitive, at any rate, in the case of microphyilous plants. It has been shown by Dr. Scott that this is the case in the Cordaiteae, the Cycadofilices, and the Calamariales, a very varied set of plants.

A medullated monostele is a very simple type of wood, and the fact that both Cheirostrobus and Lepidodendron have leaf-traces so small that they only take away a few tracheids from the edge of the wood, explains the fact that neither plant has the wood broken up into bundles.

The second reason for regarding the Lycopodiales as allied to the Sphenophyllales is dependent on the assumption that the Psilotales are connected with the Lycopods; so far as I know the evidence for the latter connexion is not much stronger than the first.

Even if the Sphenophyllales are at all closely connected with the Lycopodiales (and that they are connected in some degree I do not wish to deny) it has yet to be shown that the primitive ancestor had a sporophyll of the type of S. Dazesoni or S. trichomatosum. As Dr. Scott pointed out in his original description of Cheirostrobus, that cone seems to be in many ways the most primitive of the known Sphenophyllaceous cones. I do not see how the Spencerites cone could be derived from a cone at all resembling that of Cheirostrobus.

Finally, the idea advocated by Miss Sykes that the 'ventral hump' of Spencerites, the sporangiophore of Palaeostachya, and other similar structures are of axial origin and homologous seems to me to rest on a misconception of the nature of the evidence.

The idea seems to one, who, like myself, was not trained in the ideas of rigid morphology, derived from the higher Angiosperms, rather forced when applied to Tmesipteris, but when extended to the cones of the Lycopodiales, none of which show the slightest trace of such derivation, it seems quite inconceivable.

\section{SumMary.}

The new genus Mesostrobus is founded for a small Lepidodendroid cone ( $M$. Scottii sp. nov.) from the Mountain $4 \mathrm{ft}$. Mine of the Lancashire Lower Coal Measures.

The cone strongly resembles that of Lepidostrobus, but differs in the fact that the sporangium is only attached to the distal half of the horizontal 
portion of the sporophyll. The ligule is set in a deep ligular pit, and is somewhat large when compared with its condition in Lepidostrobus.

It is suggested that the type of sporophyll represented by Bothrodendron mundum, the male Miadesmia, and Selaginella is a close copy of a very early Lycopodiaceous type. Lepidostrobus would be derived from a cone having sporophylls of this type, on the adoption of an arboreal habit by the heterosporous Lycopods, because radial elongation of the sporangium is the most economical way of increasing the number of spores produced, a necessity for a large tree.

If this elongation takes place in the part of the sporophyll between the axis and the insertion of the sporangium, we arrive at a condition much like that of Spencerites, and from that condition we can pass through Mesostrobus to Lepidostrobus.

The fact that two branches of one stock, differing in important characters, tends to follow similar courses during their evolution is one very strongly borne in on students of Palaeozoology, and it is suggested that a similar parallelism is to be found between the homosporous and the heterosporous Lycopods; and that Spencerites, which is probably homosporous, has been derived from a cone resembling that of Bothrodendron mundum, in consequence of that increase in size of the homosporous stock which we see in the genus.

The peculiar feature of the Spencerites cone, the peltate expansion of the horizontal portion of the sporophyll between the sporangium and the lamina, is to be regarded as having a utilitarian purpose, that of affording protection to the very weakly attached sporangium. It is further pointed out that the idea that Spencerites is an ancient and archaic type rests entirely on the assumption that the 'ventral hump' is derived from a sporangiophore homologous with that of Sphenophyllum Dawsoni, and on the further assumption that the Lycopods in general are derived from a Sphenophyllaceous or proto-Sphenophyllaceous ancestor. It is pointed out that the evidence in favour of this view is really extremely slight, although there is also not much against it.

I wish to express my thanks to Prof. F. E. Weiss and Dr. W. E. Hoyle for allowing me to describe the unique series of sections of Mesostrobus now in the Manchester Museum.

I hear from my friend $\mathrm{Mr}$. W. T. Gordon that he has a cone showing similar morphological characters from the petrified plant material of lower carboniferous age at Pettycur. I look forward with interest to his description of this cone. 


\section{APPEndix, WRitten February i 9, 1909.}

Since the above account of the affinities of Spencerites was written, I have seen Dr. Lang's paper dealing with the same subject published in the Proceedings of the Royal Society of Edinburgh, vol. xxviii, p. $35^{6}$.

Dr. Lang discusses the morphology of the cone of Lycopodium cernuum, and points out that, after the disappearance of certain mucilaginous areas, the radial section of a sporophyll resembles that of Spencerites insignis: he therefore concludes that the Spencerites sporophyll, as we know it, is only the remnant of a much larger mass of tissue, much of which has broken down into mucilage, and that there is some genetic connexion between the two species.

Dr. Lang shows that in the cone of Lycopodium cernuum the sporophylls, which are arranged in alternating verticils, are connected with one another, and brings forward certain evidence to show that in some cases the distal parts of the sporophylls of Spencerites insignis may be confluent, and from this draws the conclusion that their proximal parts must have formerly had a similar connexion.

Lang concludes that the outgrowth which actually bears the sporangium in Spencerites is of no morphological importance, a view which it will be noticed is in agreement with my own.

$\mathrm{He}$ also denies any justification for the view that the portion of the sporophyll between the insertion of the sporangium and the axis is of axial nature.

He states that in Lycopodium cernum this region appears late in ontogeny. The theory of the development of Lepidostrobus and Spencerites, outlined above, requires this very region to elongate comparatively late in the phylogeny of those genera. The comparison between the observed fact of its late appearance in ontogeny in Lycopodium cermum, of which I was formerly unaware, and the assumed late appearance in phylogeny of the same region in Lepidostrobus, seems to add considerably to the probability of my explanation of the origin of that genus.

I. The whole weight of Lang's conclusion with regard to the affinities of Spencerites rests entirely on a detailed comparison of certain points in the anatomy of one recent species with a Carboniferous species of a very distinct genus.

It is, I think, obvious that comparison of two more or less promiscuously picked species of different genera is far from satisfactory evidence from which to draw important conclusions, even if the species are of the same age : if, as in this case, their relative ages are immensely different the method becomes even more risky. It is unfortunate that the use of this method appears to be on the increase amongst botanists.

2. Comparison of Fig. I of Dr. Lang's paper with my Text-figures 
I and 4 will show that Lycopodium cermum far more resembles Mesostrobus in the morphology of its sporophyll than it does Spencerites. The resemblance in the mode of attachment of the sporangia is apparently exact, the shape of the sporophyll of Lycopodium cernum after the removal of the mucilaginous areas is extremely like that of Mesostrobus, there is in Mesostrobus the same 'dorsal lobe' at the distal end of the sporophyll, and the same more or less peltate form. In fact, if Lang's explanation applies to Spencerites it must also apply to Mesostrobus ; that is, the known part of the sporophyll of Mesostrobus should have been surrounded on the lower side by a mass of tissue which has broken down into mucilage. Now the stalk of the sporophyll of Mesostrobus is a neatly finished affair of triangular section. The actual preservation of the sections is not very good, but it appears to be certain that the under surface of the stalk is completely covered by an epidermis, in which I have been able to see what I believe are stomates.

If Lang's explanation applies to Mesostrobus it must also apply to Bothrodendron mundum, the sporophyll of which only differs in the shortness of its stalk from Mesostrobus, and to Lepidostrobus, in which this region is elongated. It is, I think, unnecessary to point out the improbabilities of this position.

3. There is not the slightest direct evidence that the pedicel of the Spencerites sporophyll is not a complete organ. It is apparently surrounded by one of the most definite epidermises known in fossil plants, as may be seen, for example, in Dr. Scott's Fig. I I and Miss Berridge's Phot. 7.

4. The sporangia are closely packed in the case of Spencerites, and fill up the whole space available with the exception of that occupied by the pedicels (cp. Dr. Scott's Fig. I I, Williamson's Fig. 55, and Text-fig. 3 of this paper).

It is possible that this might be explained on Dr. Lang's theory by assuming that the mucilaginous portion disappeared before the growth of the sporangia ceased.

5. Dr. Lang's theory provides not the slightest explanation of the origin of the ventral process, and takes no account of the utilitarian purpose of the whole arrangement of the peltate ends of the sporophylls.

This utilitarian purpose is fact, not theory; see, for example, the lower left-hand corner of Dr. Scott's Fig. 3 and Text-fig. 3 of this paper; here the peltate expansions form a close-fitting mosaic, affording magnificent protection to the sporangia.

6. With regard to the possible coalescence of the distal ends of the sporophyll it is impossible to express an opinion without seeing the original preparations on which that opinion is based.

Williamson's ('78), Fig. 53, is a particularly unconvincing one, and the section appears to be very abnormal : it is according to Lang cut near the 
tip of the cone. The sporophylls are far more closely set than usual, and from the drawing it appears that their peltate heads have been destroyed.

I have carefully examined some twenty sections of cones of Spencerites, and have seen no trace of this coalescence.

Assuming that the distal ends of the sporophylls are in some cases confluent, I cannot see the logical necessity of assuming that the pedicels must therefore have been coherent at some period. It is quite probable that the adherence in the Williamson section (if really present) is teratological, and I believe that botanists are now becoming chary of using such evidence.

I. might point out here that the enclosure of each sporangium in a cell by outgrowths from the sporophylls, which Dr. Lang has shown to take place in Lycopodium cernuum, is paralleled by the condition of the Calamitean cone Calamostachys Grand'Euryi, Ren., where the sporangia are isolated in groups of four by outgrowths from the bracts above and below.

I would finally point out that Dr. Lang's theories of Spencerites must be accepted in their entirety or not at all.

A further Note on Dr. Lang's Paper, added April 28, igo9.

I have now examined the section in the Williamson collection on which Dr. Lang relies for his opinion that the sporophylls of Spencerites insignis were united distally.

The section is somewhat thick, and the cone had certainly been much macerated before petrifaction.

Those palaeobotanists who have worked much with sections of coalballs will know the great difficulty of determining whether two adjacent organs are in continuity or not under such conditions.

From a careful examination of the section I came to the conclusion that there was no evidence to show that the sporophylls in question were really organically connected. The tissue of the peltate expansion is seldom well preserved, and in the section under discussion is very much crushed; under these circumstances the evidence is certain to be of the weakest.

Text-figure 5 of this paper is a camera lucida drawing of a portion of a tangential section of Spencerites insignis of which another portion is shown in Fig. 3.

In this section the three sporophylls $B, C$, and $D$ appear at first sight to be organically connected.

With an $8-\mathrm{mm}$. Zeiss apochromatic objective, however, it is quite evident that this appearance is completely deceptive; sporophyll $C$ is cut through the attachment of the sporangium, and the section also cuts the sporangium wall parallel to its surface, this wall passes under the edges of 
the peltate expansions of sporophylls $B$ and $D$, which are also cut very nearly parallel to their surfaces.

It would have been impossible to have determined this point with an inferior lens.

I do not publish an enlarged drawing of this area because it is not

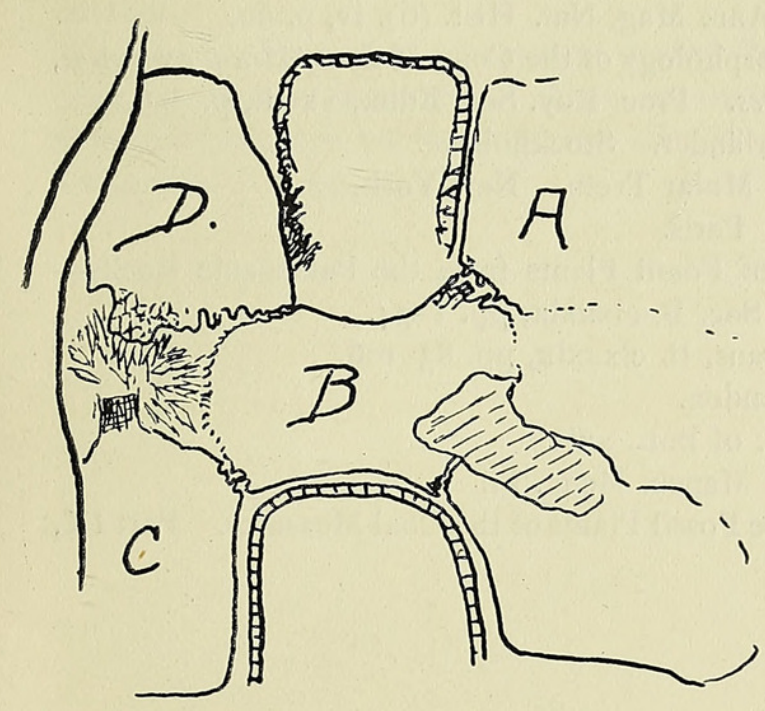

Text-Fig. 5. Another portion of the same cone. $\times 20$. To show the way in which the sporophyll $B$ fits on to $A, C$, and $D$. Shows also the attachment of a sporangium to $C$. Further described in the text.

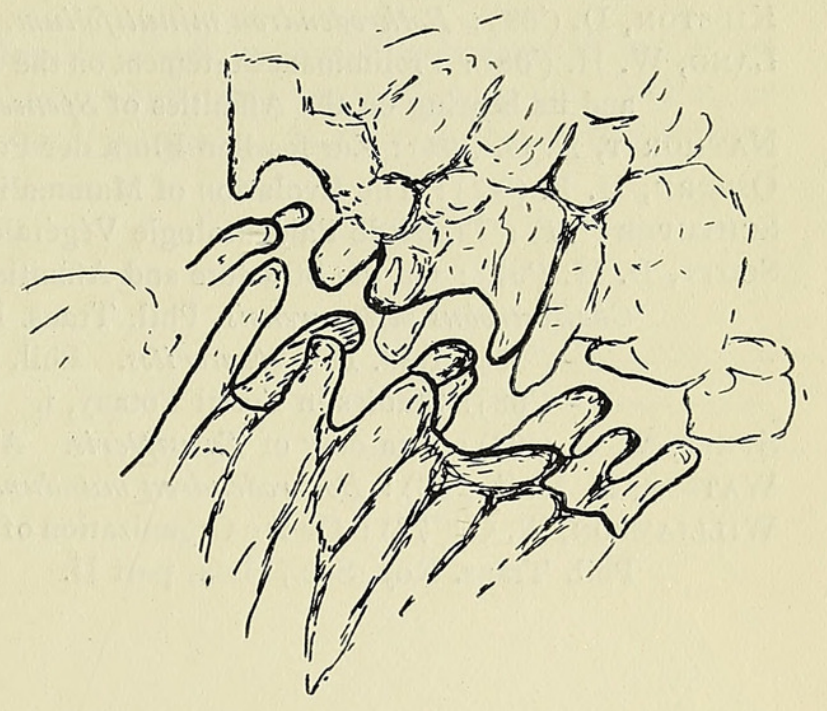

Text-Fig. 6. A portion of Fig. 3 enlarged. $\times$ I60 approx. This shows the area where sporophylls $A$ and $B$ approach closely. Further described in the text.

essential for my purpose, and my artistic ability is not sufficient to represent it adequately in two dimensions.

Sporophylls $A$ and $B$ very nearly meet, and the spot where they do so corresponds with the place in the Williamson section, where Dr. Lang believes them to be confluent. Text-figure 6 is an enlarged drawing of portions of the two sporophylls where nearest together; their edges are provided with a forest of hairs which interlock.

Such a region in a crushed and macerated specimen might very easily be taken to show actual continuity, as I believe Dr. Lang has done in the case of the Williamson section. 


\title{
BIBLIOGRAPHY.
}

Benson, M. ('08) : Miadesmia membranacea. Phil. Trans. R. Soc. B. cclx, pp. 409-25.

Berridge, E. M. ('05) : On Two New Specimens of Spencerites insignis. Ann. of Bot., xix, pp. 273-9.

Kidston, D. ('89): Bothrodendron minutifolium. Ann. Mag. Nat. Hist. (6), iv, p. 60.

LANG, W. H. ('08): Preliminary Statement on the Morphology of the Cone of Lycopodium cermum, and its bearing on the Affinities of Spencerites. Proc. Roy. Soc. Edin., xxviii, p. 356.

Nathorst, A. G. ('94): Zur fossilen Flora der Polarländer. Stockholm.

Osborn, H. F. ('07): The Evolution of Mammalian Molar Teeth. New York.

Schimper ('74) : Traitélde Paléontologie Végétale. Paris.

Scott, D. H. ('97): On the Structure and Affinities of Fossil Plants from the Palaeozoic RocksCheirostrobus pettycurensis, Phil. Trans. R. Soc. B. clxxxix, pp. I-34.

('98): Ibid. II-Spencerites. Phil. Trans. B. clxxxix, pp. 83-106.

('08): Studies in Fossil Botany, i. London.

Sykes, M. G. ('08): Anatomy of Tmesipteris. Ann. of Bot., xxii.

Watson, D. M. S. ('08) : Bothrodendron mundum. Manch. Mem., lii.

Williamson, W. C. ('78) : On the Organization of the Fossil Plants of the Coal Measures. Part IX, Phil. Trans. Roy. Soc., clxix, part II.

\section{EXPLANATION OF PLATE XXVII.}

\author{
Illustrating Mr. Watson's paper on Mesostrobus.
}

All the figures are untouched photographs. Phot. I by Flatters and Garnet, Manchester, the rest by the Author.

Phot. I. A complete transverse section of the cone of Mesostrobus Scottii, sp. nov. This gives a good general idea of the build of the cone. At $a$ are seen two sporophylls cut so near to the axis that the sporangia are not yet attached. This section also indicates the distribution of the sclerized patches in the outer cortex. R. II22. 3. Manchester Museum Collection. $\times$ 6.I.

Phot. 2. Transverse section of the 'bud' at the tip of the cone. At par will be seen the two patches of parichnos in a leaf-base. R. II 22. I. Manchester Museum Collection. $\times$ I5.

Phot. 3. The axis of the section represented in Phot. 2 enlarged. Shows the wood $x y$., the concentration of the leaf-traces l.t. in the zone of the inner cortex and Phloem, which are in this section defective, some remains of the middle cortex, and the outer cortex with the leaf-trace, surrounded by its parenchymatous sheath passing out through a hole in a sclerized patch of the outer cortex. R. II 22. I. Manchester Museum Collection. $\times 45$.

Phot. 4. A portion of the original of Phot. I enlarged. Shows the wood $x y$., phloem ph., and inner cortex $i_{\text {.c. }}$, and the middle cortex m.c., quite well preserved. The photograph shows also the insertion of three sporophylls, to none of which is a sporangium attached; the one shown completely in the photograph is the section cut furthest from the centre to which a sporangium is not attached, and I think from the form of the upper surface, which it must be remembered is cut obliquely, so that all projections appear much magnified, is very near the point where the sporangium becomes attached to the sporophyll. R. II 22. 3. Manchester Museum collection. $\quad \times 26$.

Phot. 5. A transverse section showing a sporophyll with a sporangium attached. R. II22. 2. Manchester Museum Collection. $\times$ I8.3. 
Phot. 6. A portion of a transverse section showing the distal ends of two sporophylls $s p^{\prime}$ and $s p^{\prime \prime}$. In $s p^{\prime}$ the vascular bundle is cut twice at $v b^{\prime}$ and $v b^{\prime \prime}$, first at $v b^{\prime}$ before dropping below the ligule, and at $v b^{\prime \prime}$ when rising to go into the lamina; at $l g$ is seen the ligular pit which lies between the two points of section of the vascular bundle; with a lens it may be seen that the tissue on each side of $v b^{\prime}$ is reminiscent of parichnos.

The sporophyll $s p^{\prime \prime}$ is cut lower down than the one just described; it shows a longitudinal section of the vascular bundle at the bottom of the loop below the ligule. On each side of it is a defective patch probably representing the parichnos. R. II 22. 3. Manchester Museum Collection. $\times 15.6$.

Phot. 7. Portion of a transverse section showing the distal portion of a sporophyll just at the point of origin of the lamina. At $g r$ is seen the grove which continues the ligular pit. Notice the defective parichnos on the left-hand side of the vascular bundle. R. II 22. 4. Manchester Museum Collection. $\times 14$. 
Annals of Botany
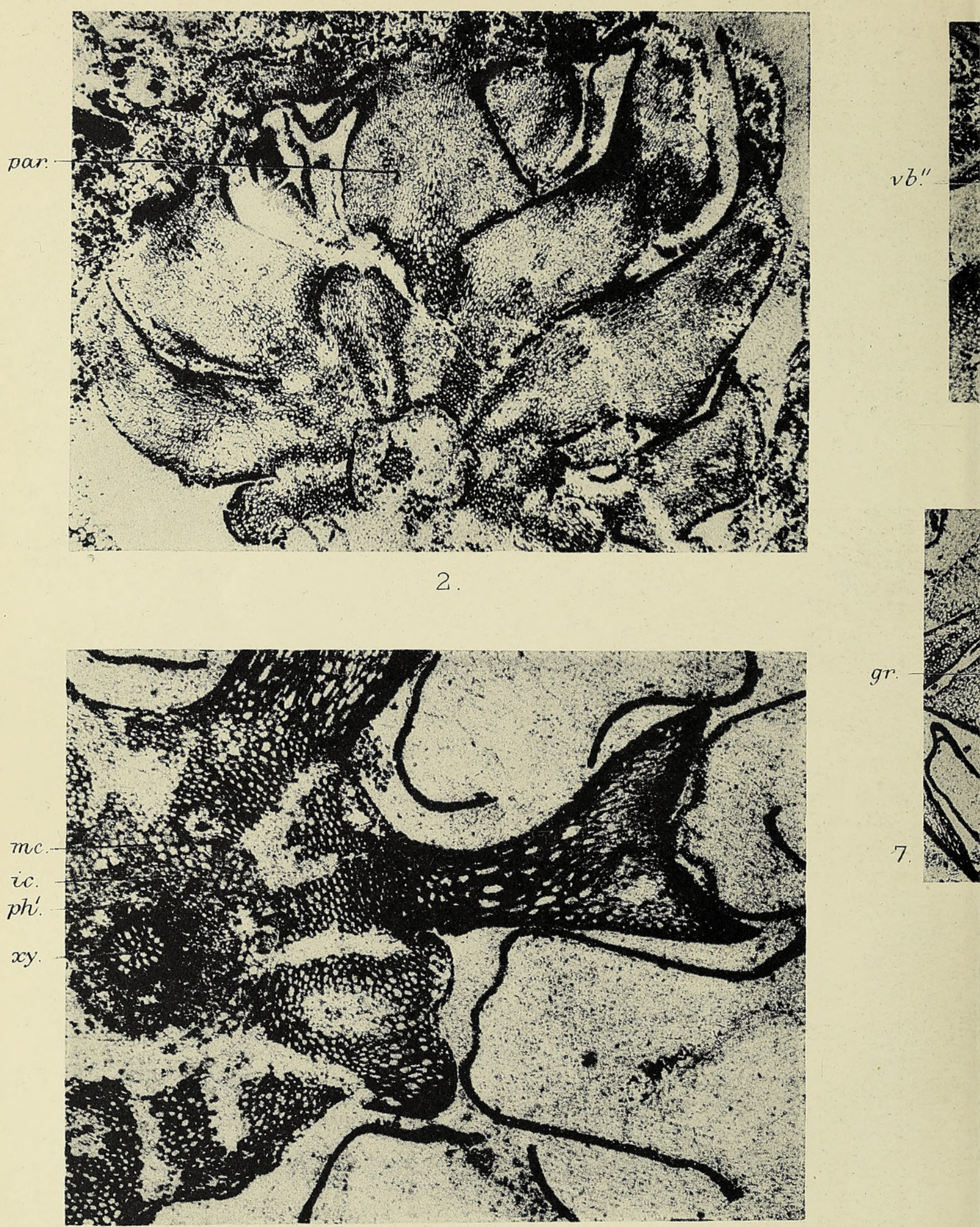

$g r$

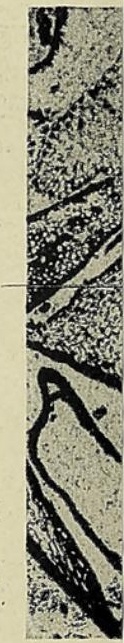

4

WATSON - MESOSTROBUS SCOTTII 

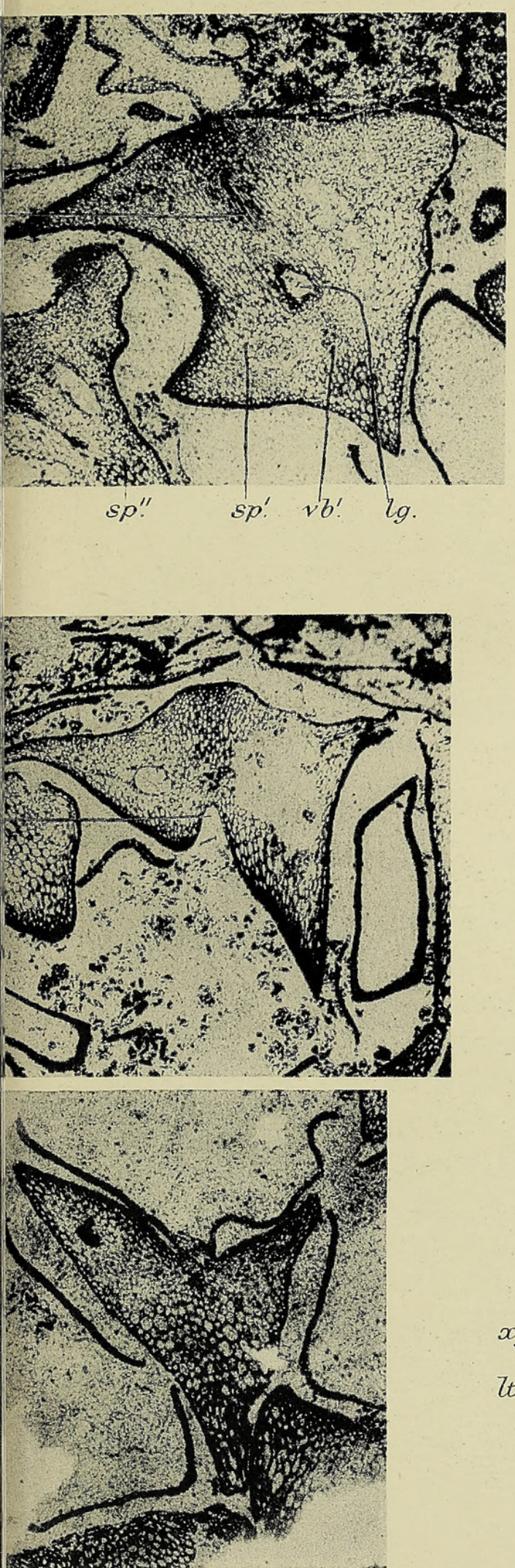

5

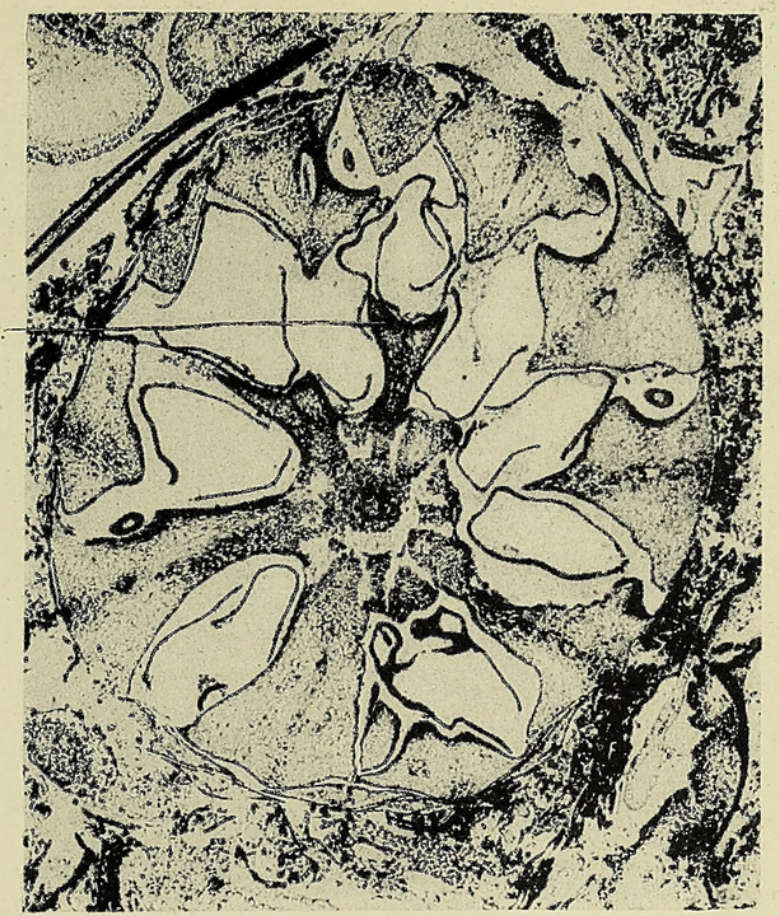

1

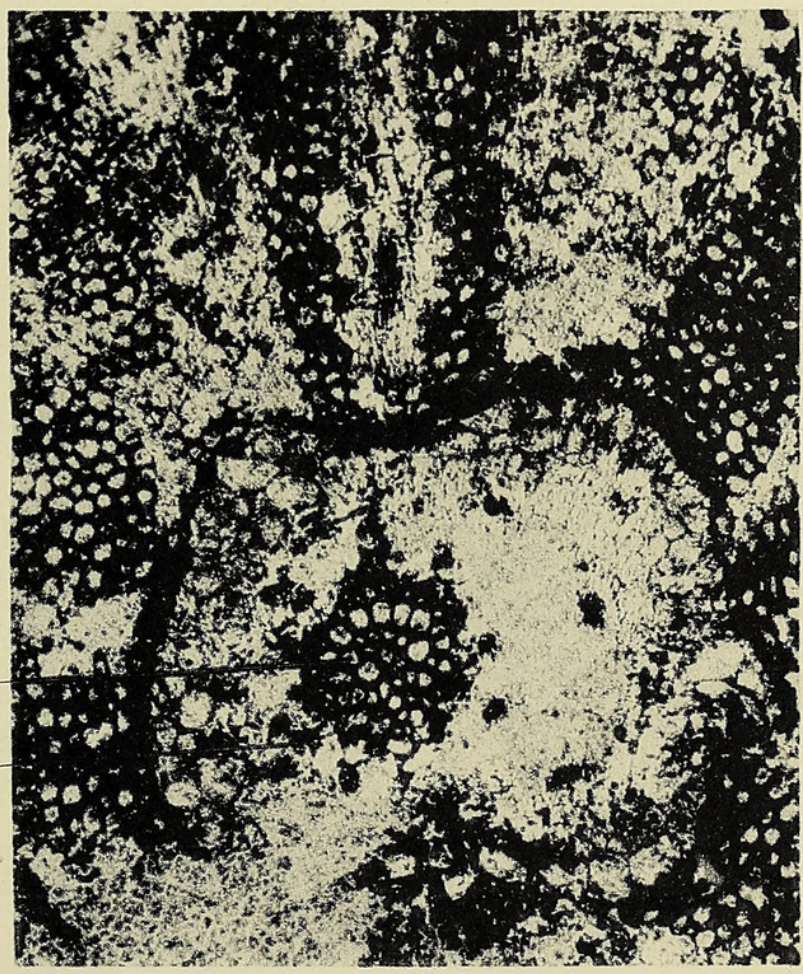



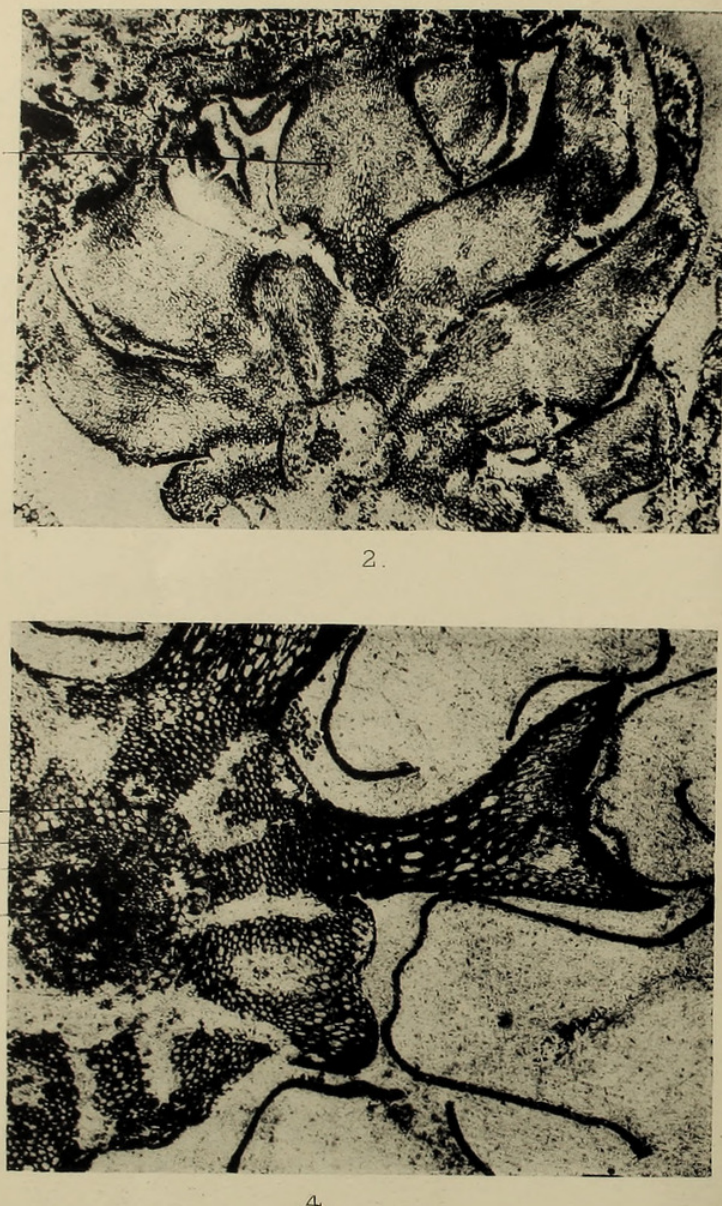
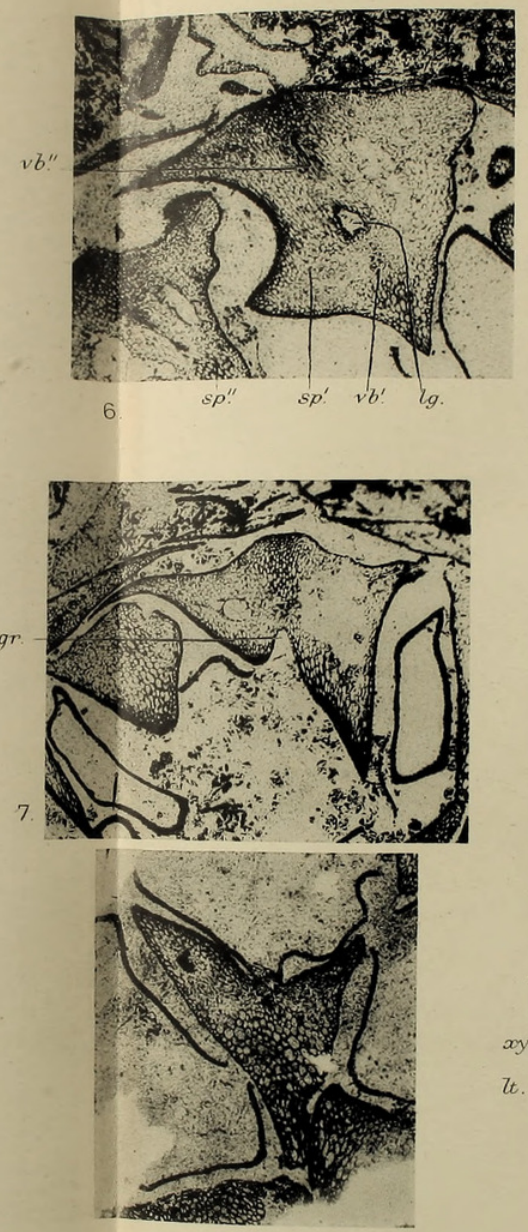
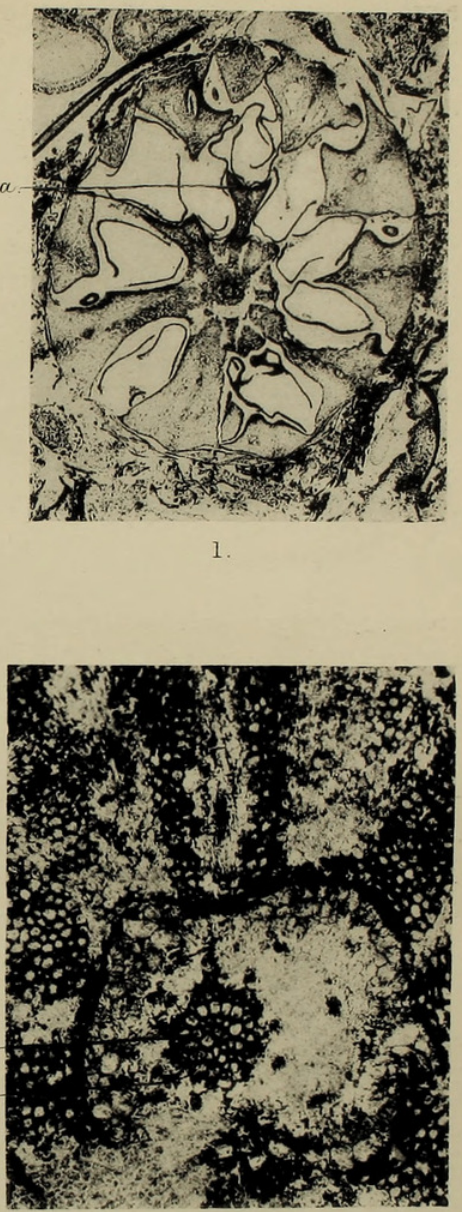

3. 

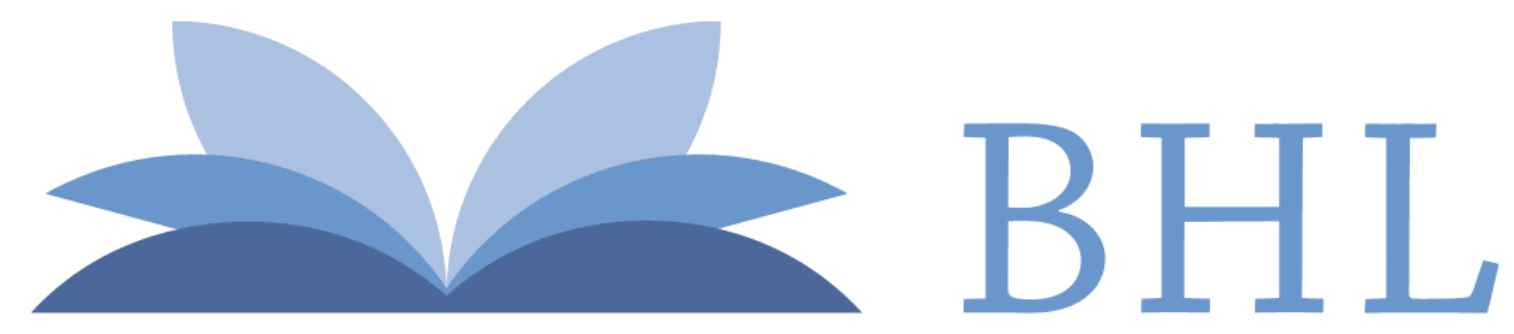

\section{Biodiversity Heritage Library}

Watson, David Meredith

Seares,

ๆ

阝

. 1909. "On Mesostrobus, a new genus of Lycopodiaceous cones from the lower coal measures, with a note on the systematic position of spencerites." Annals of botany 23, 379-397.

https://doi.org/10.1093/oxfordjournals.aob.a089227.

View This Item Online: https://www.biodiversitylibrary.org/item/236540

DOI: https://doi.org/10.1093/oxfordjournals.aob.a089227

Permalink: https://www.biodiversitylibrary.org/partpdf/318962

\section{Holding Institution}

Smithsonian Libraries

\section{Sponsored by}

Biodiversity Heritage Library

\section{Copyright \& Reuse}

Copyright Status: Not in copyright. The BHL knows of no copyright restrictions on this item.

This document was created from content at the Biodiversity Heritage Library, the world's largest open access digital library for biodiversity literature and archives. Visit BHL at https://www.biodiversitylibrary.org. 